\title{
Independent electoral management bodies and international election observer missions: any impact on the observed level of democracy? A conceptual framework
}

\author{
Anne van Aaken
}

Published online: 13 January 2009

(C) Springer Science+Business Media, LLC 2009

\begin{abstract}
What kind of institutions are needed to stabilize and foster democracy? Clearly elections are crucial and much of the institutional and legal surrounding of elections has been subject to research. Two institutional variables have been neglected though, specifically in empirical research: Electoral Management Bodies (EMBs) and International Observer Missions (EOMs). Can EMBs and EOMs foster free and fair elections? If yes, under what conditions? And what kind of competences are needed for them? We hypothesize that both can become crucial institutions for free and fair elections. Whereas independent central banks or audit courts control special issue areas in order to take certain decision out of the realm of politics, EMBs control the moment of the set-up of government - the election, when conflicts of interest of politicians are at its peak. Although other kinds of independent administrative agencies have been the subject of political science and economic research, EMBs and EOMs have also been neglected here. This article undertakes to outline a conceptual framework for testing various hypotheses on the institutional set-up of EMBs. Hypothesizing that de iure and de facto independence of EMBs foster fair elections, the detailed institutional set-up of EMBs as independent variable is outlined in order to test for the level of democracy as a dependent variable. Furthermore, the importance of EOMs as well as their interaction effect with EMBs is analyzed. Although by now EOMs are sent to almost any country with elections, their impact has not been analyzed in an encompassing way in spite of that the mission have intensified in their work, have become more costly and their verdicts are gaining ever more publicity.
\end{abstract}

Keywords Independent administrative agencies · Electoral commission · Democracy · International election observation · Positive political theory

\footnotetext{
A. van Aaken $(\bowtie)$

Max Schmidheiny Foundation Tenure-Track-Professor for Law and Economics, Public, International and European Law, University of St. Gallen, Guisanstr. 36, St. Gallen 9010, Switzerland

e-mail: anne.vanaaken@unisg.ch
} 
JEL Classification $\mathrm{K} 0 \cdot \mathrm{K} 3 \cdot \mathrm{H} 1 \cdot \mathrm{H} 7$

While democracy must be more than free elections, its also true ... that it cannot be less. ${ }^{1}$

\section{Introduction}

Democracy is a peaceful procedure for the change of government but it is often endangered especially if a government assumes that it may not be re-elected and lose power. Democratic governments are defined as being accountable to the electorate. But that might be insufficient for a well functioning democracy; they must also be subject to restraint and oversight by other public agencies: this is the idea of checks and balances. ${ }^{2}$ It is not sufficient that citizens control the state (vertical accountability). The state organs must also mutually control themselves (horizontal accountability). ${ }^{3}$ But even that might be insufficient. A further accountability dimension for governments has become ever more important: the international one. In the context of elections, this can mean the requirement for an election to comply with political commitments made by a country through its membership in international organizations such as the United Nations, the Organization of American States (OAS), the African Union, the Organization for Security and Co-operation in Europe (OSCE) or international legal commitments through its ratification of universal or regional treaties such as the International Covenant on Civil and Political Rights. ${ }^{4}$ The compliance with its obligations is monitored ever more by international election observer missions (EOMs) of International Organizations (OSCE, European Union etc.) as well as Non Governmental Organizations (NGOs). ${ }^{5}$

\footnotetext{
${ }^{1}$ Former UN Secretary General Kofi Annan, Speech at the International Conference "Towards a Community of Democracies" (Warsaw, 27th June 2000). Press Release SG/SM/7467, www.un.org.

2 Early on (Madison 1788).

3 On the notion of vertical and horizontal accountability, see (Diamond et al. 1999). Whereas vertical accountability refers to the control of government through mass media, civil society and citizens, horizontal accountability refers to the capacity of state institutions to check abuses by other public agencies and branches of government.

4 A right to democratic governance is regarded as an emerging human right. Seminal (Franck 1992). See also the references to International Human Rights law, especially Art. 25 International Convenant on Civil and Political Rights as well as Art. 21 Universal Declaration of Human Rights, Art. 3 of the Protocol to the European Convention on Human Rights, Art. 23 American Convention on Human Rights, Art. 13 African Convention on Human and People's Rights. Art. 21 UDHR states that: (1) Everyone has the right to take part in the government of his country, directly or through freely chosen representatives. [...] (3) The will of the people shall be the basis of the authority of government; this will shall be expressed in periodic and genuine elections which shall be by universal and equal suffrage and shall be held by secret vote or by equivalent free voting procedures."

Furthermore, democracy is often held to foster all kinds of desirable things, such as development, welfare, autonomy, and security.

5 (United Nations 2005), Para 4 defines international election observation as follows: "International election observation is: the systematic, comprehensive and accurate gathering of information concerning the laws, processes and institutions related to the conduct of elections and other factors concerning the
} 
What kind of institutions are needed to stabilize and foster democracy? Much of the institutional and legal setting of elections has been subject to research, but two institutional variables have been neglected so far, specifically in empirical research: Electoral Management Bodies $\left(\mathrm{EMBs}^{6}\right)$ and EOMs. The questions that we ask in this paper, hence, are: Can EMBs and EOMs foster free and fair elections? If yes, under what conditions? And what kind of institutional set-up is adequate and what kind of competences are needed for them? Are there any interaction effects between those two commitment devices EMBs and EOMs?

EMBs as one species of Independent Administrative Agencies (IAAs) are usually not at the forefront of the discussion on democracy, but - as I intend to show-can become crucial as an institution when talking about democracy in the sense of free and fair elections. Whereas most states hold elections, ${ }^{7}$ the fairness of the election and the free expression of the voters' will is by no means guaranteed. Elections can be unfair, either because they are intentionally rigged, because campaign conditions disproportionally favor the incumbent, or because administrative inefficiencies exist. Election outcomes can also be ignored for several reasons, e.g., because the winning party is deemed to abolish democracy in the future (as e.g., in Algeria 1991/1992). Whereas independent central banks or audit courts control special issue areas of politics, EMBs control the moment of the set-up of government-the election; a crucial moment as the de facto accountability of governments depends on it. Unfair elections or electoral set-ups destroy the roots of accountability. If the reelection constraint on politicians is the most powerful mechanism for re-alignment of the citizens-principal with the politicians-agents interests, the moment of reelection is also the most sensitive moment as potential conflicts of interest of the agent is at its peak: on the one hand, she has to stand for re-election in order to achieve legitimacy by holding free and fair elections, on the other hand, there is a strong incentive to rig elections in order to stay in power. One solution for mitigating the problems are EMBs. Elections are a necessary condition but may not be sufficient for making governments accountable. ${ }^{8}$ Nevertheless, this necessary condition for accountability has been neglected in so far as the institutional delegation to an independent agency conducting the elections is concerned. Depending on their set-up, they are able to prevent intentional rigging and/or administrative inefficiencies. EOMs might help in both tasks by interacting with the EMB and by providing international assistance and publicity. There are different

\footnotetext{
Footnote 5 continued

overall electoral environment; the impartial and professional analysis of such information; and the drawing of conclusions about the character of electoral processes based on the highest standards for accuracy of information and impartiality of analysis."

6 Those agencies take different names, have a variety of shapes and sizes, with a wide range of titles to match, which include 'Election Commission', 'Department of Elections', 'Electoral Council', 'Election Unit', or 'Electoral Board' or 'electoral management body' (EMB). See (International Institute for Democracy and Electoral Assistance 2006, p. 5).

7 (Freedom House 2008) finds that 123 countries out of 193 were democratic in 2006.

${ }^{8}$ Here, different conceptions, namely thin and thick notions of democracy come to the fore, see for the former (Dahl 1971). In this paper, that discussion is not of relevance as EMBs and their role in securing legitimate elections are in any case part of every thin notion of democracy.
} 
ways of international "intervention" in national elections: they might solely observe the election, they might provide technical assistance by legal and logistic advice, they might conduct poll worker training and voters' education. They may also supervise the election in that they intervene and certify each step of the electoral process. In rare cases, where there is no governance structure in place, EOMs may even administer the election themselves, as, e.g., in Kosovo or East Timor. In those cases they substitute for the lack of a governmental authority.

Accountability of both governments and parliaments through a check on the electoral process by EMBs and EOMs can be-and has been-viewed upon from different angles but there has been no connecting discussion and to my knowledge never an encompassing cross-country empirical testing. One strand of political science literature has been preoccupied with EMBs but rather in a qualitative manner or with very few countries being compared. No systematic and detailed description of the institutional set-up of EMBs has been conducted. Empirically, large scale panel studies are not existent to my knowledge. ${ }^{9}$ Especially NGOs ${ }^{10}$ and International Organizations concerned with democracy and human rights, as, e.g., the UN, the EU, and the OSCE have been collecting information on the electoral process and the institutional set-up of EMBs as well as on single elections but lack theoretical background as well as empirical testing. Furthermore, the institutional details covered are not adequate to discover the devil in the detail of the institutional set-up. We will nevertheless refer to that literature. Furthermore, some empirical testing has been done on EOMs but is restricted to a small sample of countries and covers only parts of the tasks of EOMs. Donno (2006) tests a model of the strategic interactions between the incumbent, the domestic opposition and the EOM and finds that opposition allegations and mobilization are significantly more likely in the presence of EOMs. Hyde (2004) finds that the presence of international observers increases the probability that an opposition party will choose to boycott the election. Their interaction effect with an EMB has not been looked at.

The main argument of this paper is that the institutional set-up of EMBs, and in particular their independence from government, is one important variable influencing the fairness of elections in a country as it might alter the game for the incumbents tempted to rig an election. EOMs may also alter the game for the incumbents for similar reasons. They are another way of outsourcing and committing oneself to an honest election. The interaction effects of EOMs and EMBs will also be looked at.

This paper contributes to the existing literature in several ways. It constructs a theoretical framework by combining different strands of rational choice political science as well as economic literature and builds a conceptual framework for testing the effectiveness of the institutional set-up of EMBs and international observer missions on free and fair elections and thus ultimately on levels of democracy in detail. I will first outline the theoretical background, bringing together different strands of literature, then describe the relevant legal variables of IAAs in the

\footnotetext{
9 Similarly, (Mozaffar and Schedler 2002, p. 6): "neglected variable"; (Pastor 1999a, p. 2), "Scholars have sifted through dozens of variables to try to identify the causes and the consequences of democracy, but one variable that has been missing is electoral administration."

${ }^{10}$ The ACE Project is a common undertaking of NGOS and IGOs and provides ample information and advice on elections. Especially IDEA is very active in publications.
} 
abstract while connecting the discussion to a more legal comparatist approach of EMBs which highlights the institutional diversity of EMBs. This allows me to show, first, that independence is not a binary variable but is to be found on a continuum and needs to be looked at in detail (II). In the next chapter, some testable hypotheses as to which set-up of EMBs will enhance democracy most will be generated (III). The third, international dimension of election monitoring is discussed in the following chapter (IV). The last chapter concludes (V).

\section{EMBs and EOMs: why and how?}

Democracy has long been an issue of practical and theoretical discussion, including potentially necessary restrictions of the democratic principle. Though the rationale of the delegation of powers to independent and international institutions, thereby curtailing the democratic principle, has been much discussed in political economy, it has not received any special attention when it comes to the "moment of truth" of elections. In order to clarify the complexity of the issue it seems appropriate to first clarify the theoretical background used here and second, detail the institutional setup of EMBs, drawing comparisons with other independent administrative agencies.

\subsection{Theoretical framework}

Often, democracy is viewed as a system of political competition by the economic approach to democracy. ${ }^{11}$ There is, of course, one fundamental difference between economic and political competition: whereas the first is conducted in a stable legal framework set by other actors (politicians) than those competing within the rules (market participants), the second necessarily has a partial overlap in the identity of actors. Constitutional Political Economy distinguishes between constitutional and post-constitutional settings or setting the rules of the game and playing within the rules. ${ }^{12}$ In electoral settings, some of the rules are set on the constitutional level, but a lot of rules are also embodied in either simple parliamentary laws or even directives of administrative bodies. In those constellations, those actors setting the framework of electoral laws are often the same who compete for political office. This may even hold true for the constitutional level unless a constituent assembly includes only members which are not allowed to compete for political office under the constitution to be elaborated on. But tailor-made constitutions are no rarity. Of course, as time goes by, those who have participated in the constituent assembly are not identical with those persons who compete for political office anymore. But this is, unlike in the normal market setting, not a categorical distinction. That aggravates potential conflicts of interest but it also requires cooperation in setting up a fair and stable legal framework.

One strand of (mainly economic) literature is concerned with the delegation of powers on certain issue areas to either the international level or to independent agencies within a nation-state in order to mitigate commitment problems of the

\footnotetext{
${ }^{11}$ Seminal (Schumpeter 1950); (Downs 1968).

12 (Buchanan 1975).
} 
government. ${ }^{13}$ The discussion on the proliferation of IAAs in certain issue areas, such as central banks, audit courts, anti-trust bodies, anti-corruption commissions and other economic regulatory agencies has been proliferating. There, the main rationale for making agencies independent is the time inconsistency problem of politicians, potential conflict of interests (e.g., in audit courts, and data protection officers) as well as the necessity of expert knowledge. ${ }^{14}$ In EMBs we find a further rationale: transparency on the division between deliberate electoral fraud and mere inept administration of it. The institutional set-up of EMBs has been neglected in the literature on IAAs, although EMBs are one kind of them.

Rational choice political science literature which has also been influential for the economic literature on IAAs, has advanced the idea that a stable democracy depends on a self-enforcing equilibrium. ${ }^{15}$ The fundamental question asked by this literature concerns democratic stability. Why should an incumbent party or government that has lost an election accept its loss instead of subverting the democratic process in order to retain power? The answer is that sustaining democracy requires it to be selfenforcing: it must be in the interest of the incumbents to accept their loss. ${ }^{16}$ That is only the case if today's losers find that the expected gain from accepting the loss exceeds the gain from subverting the election. Though institutions play a role in the pay-offs, the crucial variable in this literature is the citizens' consensus to react against the incumbents if they attempt to rig an election. That, in turn, is a function of overcoming a coordination dilemma within the citizenry which depends much on the de facto underlying structures of a jurisdiction, including distribution of wealth, religious, linguistic and ethnic fractionalization, etc. Though institutions matter in that frame, ${ }^{17}$ EMBs or EOMs get no special attention, especially not the institutional details. But the coordination possibility may hinge upon two factors. One is the possibility of gathering and campaigning, e.g., by holding election rallies. Here, the presence of EOMs may hinder the obstruction by the incumbent government, solely by registering what is going on and by providing more security for the opposition and citizens. Furthermore, the creation and availability of focal points, ${ }^{18}$ such as providing information on parties' programs or parties' behavior in the electoral process, is necessary for coordination. EMBs as well as EOMs might contribute to the creation of focal points - and thus mitigate the coordination problem of citizens.

Nevertheless, the game theoretic approach focuses mainly on the vulnerability of the incumbent. Certainly this is one of the most important dimensions for free and fair elections. But this theoretical underlying rationale can be fruitfully enriched by using a taxonomy which is able to paint a more differentiated picture of where and how EMBs and EOMs may influence the electoral process by including more dimensions relevant for democratic accountability. It therefore seems appropriate to

\footnotetext{
13 (Voigt and Salzberger 2002); (Majone 2001).

14 (Alesina and Tabellini 2004) and (Quintyn forthcoming).

15 Seminal (Weingast 1997) who reveals through game theoretic analysis the approach taken in (Przeworski 1991). This approach will also be followed here.

16 (Weingast 1997, p. 255).

17 (Weingast 1997, p. 255); (Przeworski 1991, p. 36).

18 Seminal (Schelling 1960).
} 
take a more differentiated rational choice approach to accountability dimensions following Bartolini ${ }^{19}$ and match these dimensions with the detailed institutional setup of EMBs. He identifies four, sometimes conflicting, dimensions which matter for democratic accountability: contestability, availability, decidability and vulnerability. It is hypothesized here that those dimensions may be influenced by the institutional set-up of EMBs as well as the presence of EOMs.

Contestability refers to the conditions of entry for political actors, especially parties, into the political market. EMBs may-apart from the electoral laws (such as percentage hurdles to get into parliament)_play a crucial role in several instances: if they have the competence of deciding on the qualification of entering the race, if they decide on district boundaries, if they assign quota for the access to media and public money, etc. Thus, contestability as a prerequisite of electoral competition might be influenced by EMBs. Furthermore, EOMs can exercise influence on the acceptance of parties by an EMB through soft means, e.g., in the pre-election phase by letting the EMB know that the non-acceptance of a certain party or the nonassignment of equal media time for all competitors would get the label "unfair election". Or it could warn the EMB that voting in military barracks for soldiers would not be seen as a free vote. In case the EMB has law-making functions, oftentimes the core team of an EOM advises already on electoral norms.

Availability refers to the demand elasticity of voters: how easily do voters switch parties? Many causes can "lock in" voters, e.g., religious and ethnic affiliation combined with closely knit social groups. Here, especially EOMs may take on a crucial role through lowering costs for switching party affiliation through monitoring the pre-election process and by securing a free and secret ballot. They may also lower the costs not only by fostering the decision to vote but also by helping in voter education. EMBs as well as EOMs, often in cooperation, built up citizens' participation in the electoral process, e.g., by organizing educational campaigns for de facto disenfranchised parts of the population, be it minorities or women. ${ }^{20}$

Decidability refers to the "product differentiation", that is, program or promise differentiation of the political offers. We assume that decidability is not influenced by EMBs and EOMs.

Vulnerability, i.e., the incumbents' safety of tenure, is certainly at the heart of the rationale of EMBs and EOMs. We hypothesize that both, independent EMBs as well as EOMs may change the pay-offs of the incumbents' through sanctions for rigging the elections at hand. They may also give more security to the (losing) incumbent that she might be able to win in another election by providing also for future vulnerability of the then incumbent. That presupposes that an EMB is a stable institution and its independence secured in the long run. Sanctions for rigging an election can be direct sanctions or indirect sanctions, such as reputational losses. Direct sanctions refer to the possibility of an EMB to secure that the incumbent has less possibilities to secure tenure. Much depends on the competences an EMB has for this purpose. That may range from the possibility of condemning certain

\footnotetext{
19 (Bartolini 1999, 2000).

${ }^{20}$ Binder (2008, p. 85) identifies the failing to tackle the participation of those groups as one of the short comings of EOMs.
} 
behavior publicly to excluding political actors from public office. Indirect sanctions refer to reputational losses and its consequences. They are primarily "soft" sanctions, i.e., non-legal, and come to the fore primarily through EOMs. Let's assume that the incumbent rigs the election and the verdict is "unfree and unfair election". That might influence the attitude of the international community towards that state, e.g., by shutting the country out (or not pursuing its membership application) of certain International Organizations (or committees thereof) or by cutting down development aid. Those consequences might lower the utility for the incumbent to stay in office and thus the incentive to rig the election.

Countries which have a tradition of a reliable and neutral bureaucracy dealing with core tasks such as voter registration might not need any independent EMB but can leave those tasks, e.g., with the Ministry of Interior under the supervision of their courts. ${ }^{21}$ Separating the political from the technical is a difficult task and at the forefront of making an election trustworthy. If elections are one mode of "institutionalizing uncertainty", 22 i.e., enhancing uncertainty on who gets elected (vulnerability), this substantive uncertainty has to be coupled with procedural and administrative legitimacy and certainty in order to have a free and fair election. This "defines the central task of electoral governance: organizing electoral uncertainty by providing institutional certainty." 23 Independent EMBs are less needed in countries where the administration is trusted, neutral and efficient. In established democracies, elections tend to be routine events, usually producing well accepted results, even if there is only a narrow margin. A completely flawless election does not always take place; there will always be a margin of error, inaccuracies in counting, or incomplete voter registers. As long as these errors occur randomly and do not determine the electoral result, trust in the electoral procedure will not suffer. This is not meant to imply that administrative problems in developed countries do not exist and that trust in the fairness of the system may not be shattered, especially if outcomes are tight ${ }^{24}$ but the scale of administrative potential for fraud is usually smaller in established democracies with free media and trusted administrations. Thus, the informational problem for the citizenry to know whether there has been electoral fraud or not is smaller in countries with a trusted administration and/or free media. If this informational hurdle is one hurdle for the coordination dilemma of citizens to punish politicians rigging an election (Weingast), trust-generating independent EMBs are a helpful device for stabilizing a democracy. Nevertheless, setting up independent EMBs de iure is no panacea-they also need to be independent de facto, that is, not captured by special interests.

The effect of EMBs can be enhanced by EOMs as they give a non-partisan, all encompassing and quick verdict on the election process. ${ }^{25}$ Furthermore, EOMs give technical advice-and might therefore mitigate the problem of ineptness of

\footnotetext{
${ }^{21}$ Cf. (Mozaffar and Schedler 2002, p. 15).

22 (Przeworski 1988, p. 63).

23 (Mozaffar and Schedler 2002, p. 11).

24 As the contested Florida vote count of the US presidental elections in 2000 demonstrates.

25 EOMs usually release a preliminary assessment ("statement of preliminary findings and conclusions") immediately after the election.
} 
conducting the electoral administration. There might be different signals send out to citizens and the opposition before and after an election. If no EOM is invited ex ante, that can mean two things: either the incumbent is unwilling to have any international monitoring in order to make rigging possible. Or it can signal that the elections are anyhow free and fair and no EOM is needed to observe the election. EOMs presence, although they are present also in old and well functioning democracies (e.g. Switzerland), is almost unknown to the public in those countries and they usually do not play a big role. Sometimes EOMs are invited but they decline to go as the conditions in the country either do not allow for genuine democratic elections or that security does not permit the necessary minimum conditions for an effective EOM. ${ }^{26}$ A well publicized invitation to EOMs may also signal to the citizenry that the incumbent is ready to allow free and fair elections. Inviting EOMs but then backtracking by not allowing them in the country in the usual manner sends the worst signals to citizens and to the international community. If observers cannot be assured of being able to fulfill their task which is very much a cooperative effort between the government, the national EMB, civil society actors and the observers, they usually do not go into the country (as, e.g., Russia experienced when not granting the observers of the OSCE (Office for Democratic Institutions and Human Rights; ODIHR) free access to the parliamentary elections in autumn 2007). ${ }^{27}$

The interaction effect of EMBs and EOMs can be manifold. Their interaction effect can be neutral, that is, the effect of one does not influence the effect of the other. The effect can be substitutive, that is, the tasks of EMBs or EOMs, respectively, can be substituted without effect. Voter education, e.g., may be done by both. A strong and administrative efficient EMB may be sufficient for guaranteeing a fair election without the need for an EOM and vice versa - the presence of an EOM may be a substitute for a national EMB, especially if the country has no functioning government or administration. One has to keep in mind though, that EOMs haveexcept for extraordinary cases-no legal competences whereas EMBs usually do, that is they work through different mechanisms. A substitution therefore can only be partial. The relationship may also be competitive in that both, the EMB and the EOM work in counter directions. This is to be expected especially in situations where the EMB is not de facto independent and rather a tool for the incumbent to stay in office. The effects may also be complementary, that is, the tasks fulfilled by an EMB may be enhanced and complemented by the EOM. We assume this to be the most likely interaction effect. EMBs have usually well defined tasks and EOMs support those tasks-e.g., by giving technical assistance and advice for voter registration and voter education, by pressuring the government to adhere to the rules etc. Especially in countries with weak administrative governance and unstable democracies or in

\footnotetext{
${ }^{26}$ See (Binder 2008, p. 77) for examples (Uzbekistan, Zimbabwe, Ivory Coast, Chechnya).

27 Russia first tried to limit the number of observers by saying it would accept only 70 (while 400 observed the 2003 Duma elections in Russia). Second, it delayed the issuance of visas to the observers. After 2 weeks of Russian foot-dragging on visas, ODIHR said it would not send observers to monitor the election campaign because "entry visas have continuously been denied". Eventually, ODIHR pulled out of monitoring the elections entirely, because it could not follow standard practice of observing the elections in Russia for 1 or 2 months.
} 
transition-to-democracy countries, a strong complementary effect (and even substitutive effect) of EOMs can be expected.

Assuming that there is both, a partially complementary and partially substitutive relationship depending on the tasks, how can the interaction effect of EMBs and EOMs be characterized? There are two most likely effects. If the governance quality and the fairness of elections have a positive correlation, one can assume that EMBs enhance both. If EOMs are present in the country in addition to independent EMBs, they might contribute positively but with a diminishing return the higher the governance quality of a country becomes. Graphically, that would mean that we have asymptotical graphs. In other words: the effect of EOMs is higher when governance quality is low and diminishes when it gets better. Another possibility is that there is a shift effect by EOMs. But that only holds until a certain level of governance quality is reached. At high levels of governance quality, no effect of EOMs on the fairness of elections would then be found.

\subsection{The institutional set-up of electoral management bodies}

No common and clear-cut definition of IAAs, especially for the definition of independence exists. The same holds true for EMBs as one example of IAAs. Also, sometimes there is more than one body dealing with electoral tasks. With regard to IAAs, conflicting goals-democracy/legitimacy on the one hand and interest-free independent regulation on the other hand-are frequently discussed. With regard to EMBs, those goals are not conflicting as their primary raison d' être is to enhance the fairness of elections and ultimately the level of democracy. Furthermore, there are some special characteristics of EMBs which do not allow an easy comparison to IAAs in the sphere of economic regulation. Usually IAAs have a defined and narrow task tailored to avoid certain well-known conflicts of interest or the problems involved with time-inconsistent preferences of politicians. Once the relevant problem is identified, one finds quite similar institutional provisions in different countries (e.g., central bank independence which varies only minimally from an institutional point of view as their task is usually narrowly defined). ${ }^{28}$ EMBs do not lend themselves so easily to institutional comparison as their set-up and their competences for the electoral process vary considerably.

Usually, the main criterion for calling an agency independent is the freedom from direct authority exercised by the executive branch, but the degree of independence varies substantially between different (kinds of) EMBs. Legal autonomy is just a necessary but not a sufficient condition for independence. In other words, even if the agency is legally independent and does not form part of the bureaucratic structure, this does not imply that it is independent. Rather, drawing a distinction between independent and non-independent administrative agencies and EMBs, respectively, is a multi-dimensional task. It allows only for a classification on a continuum, the most important variables being the possibility of governmental instructions, the position of the head of the EMB, as well as the scope of competences of the EMB. Furthermore, the effect of legal variables often can cut both ways, depending on the

\footnotetext{
${ }^{28}$ See for details (Quintyn forthcoming).
} 
underlying political circumstances in the respective country. If, e.g., a country has highly dependent courts de facto, any judicial review would undermine even an de facto independent EMB. Countries in transition to democracy, e.g., with a highly (ethnically or religiously) fractionalized population, might be better off to choose a representative EMB (containing party affiliates of all parties) instead of an expert EMB (containing non-partisan experts). In spite of those difficulties in analyzing EMBs compared to other IAAs, an attempt will be made for systematic analysis, taking up the most important legal variables. Much of the literature on IAAs identifies four criteria of independence: institutional, personal, financial and functional. ${ }^{29} \mathrm{We}$ will follow this distinction here. Furthermore, accountability of EMBs through judicial review is shortly discussed.

\subsubsection{Institutional independence}

Institutional independence is the legal independence from government: the EMB is set-up as a distinctive legal entity. The International Institute for Democracy and Electoral Assistance (IDEA) distinguishes three basic models of setting up EMBs: the independent, the governmental and the mixed or semi-autonomous models. The crucial criteria for distinguishing an independent from a governmental model are the legal set-up as well as the non-accountability to the executive branch, although the EMB may be accountable to the legislature, the judiciary, or the head of state. Legal independence allows an IAA to sue and to be sued. Usually, if the body is legally independent from the government, it excludes the right of instructions by the ministry. ${ }^{30}$ The governmental model is characterized by the fact that there is no independent body but the electoral tasks are fulfilled by the ministries, usually the Ministry of Interior. This model highlights that much of the electoral process consists of classical administrative tasks. On the national level, usually no special personnel other than the usual civil servants answerable to a cabinet minister exist. ${ }^{31}$ The governmental model automatically includes the right of instruction by the government due to the hierarchical order of bureaucracy. Those instructions can either concern the formulation of by-laws and general instructions or also specific instructions, which in turn may allow only for questions of legality or also questions of expediency. Under the mixed model of IDEA, the policy functions (which may

\footnotetext{
${ }^{29}$ For a more thorough discussion on different types of IAAs, see (van Aaken 2005). See for this distinction referring to central banks, (Dutzler 2002, p. 496) with further references. See also (Arnone et al. 2007, p. 6 et seq.) for the assessment of autonomous central banks. For independent courts, see (Salzberger 1993, p. 352) who distinguishes substantive and structural independence. This article focuses on structural independence, that is, the institutional arrangements which enable the existence of substantive independence.

${ }^{30}$ In total, 119 countries have chosen this model of EMBs, e.g. Armenia, Australia, Bosnia and Herzegovina, Burkina Faso, Canada, Costa Rica, Estonia, Georgia, India, Indonesia, Liberia, Mauritius, Nigeria, Poland, South Africa, Thailand and Uruguay. (International Institute for Democracy and Electoral Assistance 2006, p. 304), Annex A counts 214 countries and territories.

31 (International Institute for Democracy and Electoral Assistance 2006, p. 7). Denmark, New Zealand, Singapore, Switzerland, Tunisia, the UK (for elections but not referendums) and the United States follow this model. In Sweden, Switzerland, the UK and the United States, elections are implemented by local authorities. In Sweden and Switzerland, the central EMB assumes a policy coordinating role.
} 
be law-making functions) are separated from the administrative or implementing function. Whereas the policy functions follow the independent model, the administrative functions follow the governmental model. Under this model, elections are organized by the component governmental EMB, with some level of oversight provided by the component independent EMB. ${ }^{32}$ In some cases, the independent part of the EMB is little more than a formalized observation operation, although this version is dying out, having been abandoned for example by Senegal. In other cases, the component independent EMB has a role to supervise and verify the implementation of electoral events by the component governmental EMB. Furthermore, there may be even more agencies involved, e.g. a Constitutional Council engaged in the tabulation and declaration of results. ${ }^{33}$ More than in the "pure" models, the variables may lend themselves even less for classification as policy competences, budgetary and personal independence are intermingled. This creates a problem not only for academics but also seems to lead to frictions during elections as competences are unclear. ${ }^{34}$

IDEA's international 2006 survey of electoral management in 214 countries and territories worldwide showed that $55 \%$ of all countries followed the Independent Model, 26\% the Governmental Model and 15\% the Mixed Model. ${ }^{35}$ The first quick overlook on the set-up of EMBs finds that EMBs in developed countries and democracies are usually dependent or form part of the government, respectively. Out of the 30 OECD countries, only 6 have an independent EMB, whereas 8 have chosen the mixed model and 16 have the governmental model. ${ }^{36}$ While IAAs, e.g., independent central banks, have been the invention of the developed countries to be exported to other countries later on, there appears to be no such trend-setting in the sphere of EMBs. ${ }^{37}$ A second look might give an explanation: elections are not only a highly politicized exercise but also a formidable administrative task.

\subsubsection{Personal independence}

Personal independence refers to the way the highest members of the EMB are appointed, their status and whether and under what circumstances they can be removed. Here, one finds the usual safeguards variables: are appointments for one time only or may there be re-appointment, how are the heads protected against arbitrary removal, do they have the usual immunity of judges, etc. Governmental EMBs have no personal independence as members of the EMB are part of the governmental bureaucracy. But for non-governmental EMBs, the extent of personal independence becomes crucial. Usually, members of an independent EMB cannot serve in the executive branch at the same time. Furthermore, members of an EMB

\footnotetext{
32 (International Institute for Democracy and Electoral Assistance 2006, p. 8). It is used in France, Japan, Spain and many former French colonies, especially in West Africa, for example Mali, Senegal and Togo.

33 (International Institute for Democracy and Electoral Assistance 2006, p. 8).

34 (International Institute for Democracy and Electoral Assistance 2006, p. 8).

35 The remaining $4 \%$ corresponds to countries that do not hold national level elections.

36 This list follows the IDEA categorization.

${ }^{37}$ For a different pattern of diffusion of IAAs in the economic sphere, see (Gilardi et al. 2006).
} 
can either be experts or they can be partisan. Partisan EMBs are often chosen in transition-to-democracy countries to augment trust in a neutral conduct of the elections by securing oversight of all parties concerned. Members of the EMB can be nominated by the electorate through an open procedure or they may be nominated by parties or governmental, judicial or legislative organs. The first option secures the most contestability but shifts electoral problems in the pre-election phase. Thus, it makes only sense if there is already a save environment for fair elections. Nomination by the government makes an EMB less independent, nomination by the judiciary most independent if the latter is independent.

\subsubsection{Financial independence}

Financial independence refers to the ability of having own accounts (usually in combination with institutional independence), as well as the question of who decides on the budget. A legally independent body usually also has its own budget, whereas an EMB which forms part of the government usually gets its funds out of the general budget, e.g., of the ministry of interior, subject to allocative decisions by the government. The budget falls under the budget of the ministry or local administrations. If the budget of an IAA (or EMB) is decided by government and not by parliament, that makes it easier to push IAAs in the desired direction with a predictable result on its de facto independence. The question of who allocates the budget thus may become crucial for independence. Furthermore, only if there is a sufficient budget to carry out the tasks allocated to the EMB, can one talk of de facto independence. Some EMBs have the possibility of accepting funds also from international organizations or NGOs - a possibility making them more independent from the incumbent government.

\subsubsection{Functional independence}

Functional independence defines the competences an EMB has; or put differently, the level of delegation to the EMB. Looking at it through a principal-agent framework, it might be that the principal, the government or the legislator, constrains the EMB through detailed regulation by writing almost "complete contracts". ${ }^{38}$ The discretion of EMB would therefore be curtailed. The extent of competences thus embraces the question if and how far the agency is able to set and specify its own goals. For EMBs, the tasks are usually not as narrowly defined as for other IAAs such as central banks. Their competences can be categorized as rulemaking, rule-application and rule-adjudication competences and may thus vary broadly. Can the EMB, e.g., take decisions on the passive right to vote, does it have competence for the alignment of electoral districts, etc. or other laws regulating an election, does it allocate media time to parties, does it monitor and control party and candidate financing and does it have competences for sanctioning? IDEA defines as their core or essential tasks the determination of who is eligible to vote; receiving

\footnotetext{
38 See (Mozaffar and Schedler 2002, p. 17).
} 
and validating the nominations of electoral participants (for elections, political parties and/or candidates); conducting polling; counting and tabulating the votes. Additionally, EMBs may have other tasks allocated such as the conduct of voter registration, boundary delimitation, voter education and information, media monitoring and electoral dispute resolution. ${ }^{39}$ One might view the core tasks as predominantly administrative or technical tasks irrelevant for the fairness of an election but that would be an underestimation of the potential in the more technical and administrative area to manipulate elections. Guayana, e.g., registered the deceased dictator on the voters' list. ${ }^{40}$

\subsubsection{Accountability of EMBs}

Accountability can take on many forms: it may be asked to whom (government, parliament, courts, the electorate, parties) an actor is accountable and for what kind of issues and information. Here, I concentrate on the accountability of EMBs to courts. This kind of accountability through judicial review infringes least on their independence; ${ }^{41}$ would they be accountable to parliament or the executive that would mean putting the fox in charge of the henhouse. There are several possibilities for accountability constellations: either there is no possibility of review whatsoever of any decision taken, there is only internal review, or there is judicial review. In all cases, much depends on who is allowed to lodge a complaint. Standing can be restricted to candidates, parties, or some organ of the state. It could also be extended to all citizens eligible to vote. The standing provisions for either a complaint at the EMB or a court have a gate-keeping function that might well make a difference on accountability grounds. This implies that the factual degree of accountability of the EMB depends on the independence of the courts. Indeed, even if there were a de facto independent EMB which might be overturned by a court, all depends on the latter's de jure and de facto independence. Thus, if the judicial system is biased and ineffective, it may actually subvert progress achieved in the impartial and professional administration of elections. ${ }^{42}$

\subsubsection{EMBs in the trias politica}

Generally speaking, one can place EMBs in a framework of powers, all of them defining independence and accountability through interaction, which is illustrated by the following figure (Fig. 1).

\footnotetext{
39 (International Institute for Democracy and Electoral Assistance 2006, p. 5 et seq.).

40 (Pastor 1999b, p. 133).

41 Accountability does not necessarily mean accountability to the government. Rather, an EMB may be accountable to courts only. Then, independence of courts becomes important. Furthermore, one may argue that independence and accountability of EMBs are not at cross-roads: an accountable EMB might be able to strengthen its independence from the other branches of government through enhancing its legitimacy.

42 See (Eisenstadt 2002) for electoral courts as well as (Feld and Voigt 2003) for normal courts.
} 


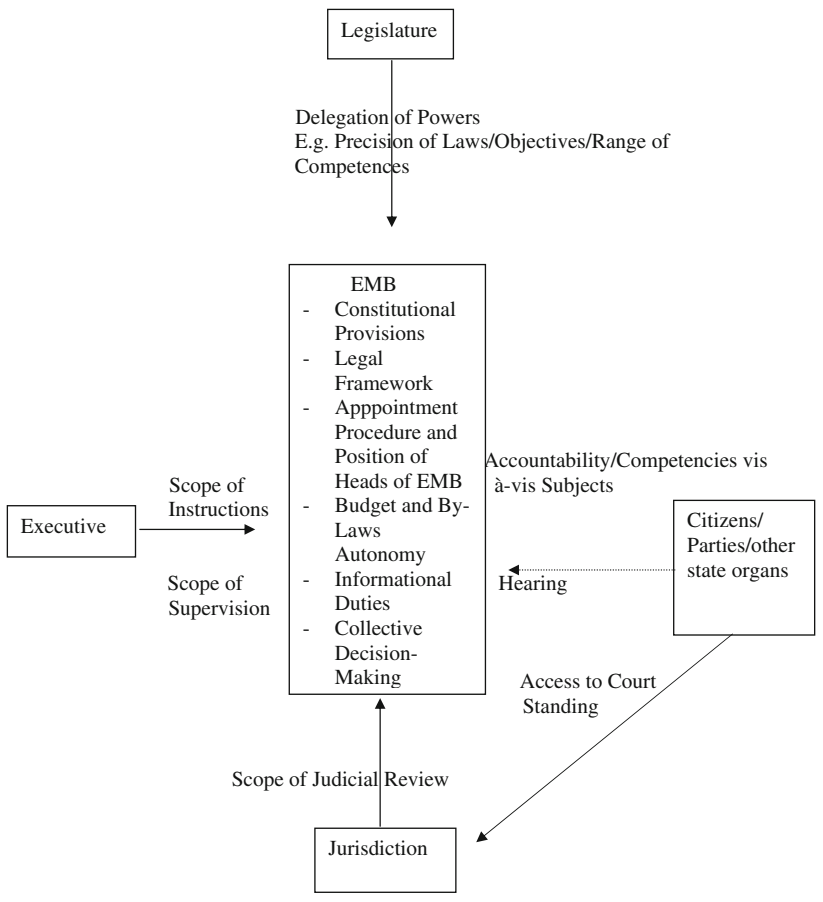

Fig. 1 EMBs within the network of state powers

In this figure, we can identify the four dimensions of independence as well as the accountability of EMBs. The delegation of powers to an EMB by the legislator refers to functional independence. The scope of instructions and supervision refers to institutional independence. Personal and financial independence are described within the set-up of the EMB itself. Accountability mainly refers to the review mechanisms an EMB is submitted to by complaints and the scope of judicial review.

\section{Does the set-up influence the level of democracy? Some hypotheses}

The level of democracy has been attributed to many factors, from economic development to colonial history and institutional variables. ${ }^{43}$ Nevertheless, the institutional variable of the set-up of EMBs has been neglected and has never, to my knowledge, been tested on a broad cross-country basis, although data is available on the level of democracy as well as a rough textured indicator of IDEA on the independence of EMBs. In my view, that latter indicator needs to be looked at more carefully which necessitates a careful legal comparatist analysis in order to find the

\footnotetext{
43 See (Lijphart 1999) and (Lipset 1959) and for a survey on economic development and democracy (Sunde 2006).
} 
interactions of legal variables described above; as usual, the devil is in the (legal) details. The following hypotheses will draw a framework for later empirical testing.

\subsection{What level of democracy?}

The first difficulty in generating testable hypotheses is already the concept of the dependent variable: the level of democracy. ${ }^{44}$ There are not only conceptual problems but also data availability problems. ${ }^{45}$ I will concentrate on the former but use a thin notion of democracy (that is elections only). Although one may agree that the level of democracy can be (partially) conceptualized by the necessary condition of free and fair elections, it is by no means clear when an election is free and fair. A first approach is to rely on the dictum of EOMs (which may have different dicta on the same election). The dictum of EOMs on an election is usually drafted in a bimodal term (sometimes a qualification is added as "substantially free and fair"). The dictum is thus a fuzzy concept with multi-dimensional elements: an election can, e.g., be fair on the administration but problematic on how the electoral districts are drawn, leaving the seats largely uncontested ("gerrymandering"). The second possibility is an objective measurement by looking at the process of the election and possible irregularities. This would call for a check-list of the steps (in a time sequence of election management). ${ }^{46}$ For a comprehensive empirical analysis that poses huge problems as first, data may not be available on all countries and elections; second, check-lists leave open the question how to weigh the points on the list and how to aggregate them. ${ }^{47} \mathrm{~A}$ third option is to use a subjective approach where various actors may be relevant. Pastor suggests that a flawed election is „one in which some or all of the major political parties refuse to participate in the election or reject the results". ${ }^{48}$ A fourth, more comprehensive subjective approach would be to ask those affected and participating, similar to the Transparency International approach for measuring corruption. In elections, citizens, grass root activists, international observers and (opposition) parties would need to be asked by opinion

\footnotetext{
44 There is, of course, a problem of endogeneity when institutions serve as explanatory variables. The problem seems to be quite severe here: on the one hand, it seems quite reasonable to assume that EOMs are much more likely to be sent if the level of democracy is low. On the other hand, it may be that only those governments that intend to hold free and fair elections allow EOMs into their countries the first place. A similar reasoning applies for independent EMBs: maybe they are only drawn up if (1) the administrative efficiency is low or (2) of the fairness of past elections has been deplorable. In other words: control for reversed causality and selection effects is needed. The standard solution is to draw on instrumental variables. Adequate instruments are usually hard to find. One possible instrument could be international aid receipts/GDP. A pragmatic solution of the problem is to look at the fairness of the last election which took place before international observer missions were sent (controlling for other exogenous shocks such as coups and so forth). A break point test could then reveal whether sending an international observer mission is identified as a structural break. A qualitative analysis of borderline cases may also help to gain empirical leverage over such issues.

45 For a discussion on the measurement of democracy, see (Munck and Verkuilen 2002).

46 (Elklit and Reynolds 2002), Table 1 (p. 92 et seqq.).

47 (Pastor 1998, p. 159) and (Mozaffar and Schedler 2002, p. 19).

48 (Pastor 1999a, p. 15).
} 
polling. That would require an "Electoral Integrity Perception Index" which, alas, does not exist yet. ${ }^{49}$ A further fifth possibility is to account for changes in government. Even ,if the proof of the pudding is in the eating, the proof of democracy is in the alternation of government", 50 that would be a very crude measure as it may well happen that governments stay legitimately in power for longer periods of time. More recent approaches try to combine (some of) those criteria. An elaborated framework for studying election quality, looking at process as well as outcome has been proposed by Elklit and Reynolds in $2005,{ }^{51}$ but there is no overall assessment usable as a data set. The advantage of their proposition is that it takes stock only of the necessary condition of democracy, the election only, but leaves out other factors in the assessment of democracy, such as education or press freedom (although those may also be important for free elections). Ideally, those variables may be controlled for separately in an empirical assessment as that would allow for more precise estimations. Although these conceptional problems are by no means solved, for an empirical study, it seems permissible to use the level of democracy variables supplied by the "Freedom House Index" or the Polity IV Project. Furthermore, one may test for electoral competitiveness as a proxy for the livelihood of political competition and the vulnerability of the incumbents. ${ }^{52}$ To sum up: no available variable is a perfect proxy for what we have in mind. Yet, some of the available variables seem to be fair proxies.

\subsection{Independent variables}

Drawing on the classification of IDEA into independent, governmental and mixed models seems too superficial to generate reliable results though they give a first overview on institutional models found. Furthermore, often, the relevant variables interact, e.g., financial independence and institutional independence. Therefore, the following hypotheses distinguish between the different modes of independence as outlined above and discuss possible interaction effects with a view to Bartolini's four dimensions of accountability.

\subsubsection{Functional independence}

As described above, the power conferred on EMBs can vary broadly: it may be restricted to purely administrative functions such as setting up the voter registry or vote counting, thus only leaving space for law application (which in turn might be controlled or not by either courts or the government). But the delegation might also be much broader: it may entail law-making functions and also adjudicatory functions. Though usually the basic framework of the electoral system, as proportional v. majoritarian system as well as the size of electoral districts is predetermined by the constitution or by parliamentary laws, it might be that the

\footnotetext{
49 (Mozaffar and Schedler 2002, p. 19).

50 (Mozaffar and Schedler 2002, p. 20).

51 (Elklit and Reynolds 2005).

52 For Indices of Electoral Competitiveness, see (Beck et al. 2000).
} 
EMB has the task of drawing district boundaries, as, e.g., in Germany, but it might also be that this task is left to the legislator with potential conflicts of interest, as in the US. Clearly, if the EMB is independent and the scope of its tasks is broad, there is less possibility for the government to take influence on the electoral process.

Depending on the competences allocated to an EMB, the other dimensions of independence (i.e., personal, functional and financial) become more important. If, e.g., the EMB can decide on the boundaries of electoral districts (rule-making), this requires a more personally independent EMB than if the competences are confined to voter registration (pure rule-application) as the conflict of interest and the possibility of rigging elections becomes even greater. In short: the more tasks relevant to the electoral process are assigned to an EMB, the more its independence defined by the other dimensions is a prerequisite for free and fair elections.

Hypothesis 1a The more tasks which involve potential conflict of interests of legislators or government are outsourced to an EMB, the fairer the electoral process will be, given that the EMB is personally, financially as well as institutionally independent. But if the EMB is personally, financially as well as institutionally dependent, no degree of functional independence is expected to have an effect on the dependent variable.

Law application, that is, administrative and technical tasks, becomes more important if the general level of the quality of administrative governance is low. Many rather technical steps in the electoral process can then be easily misused by politicians to rig elections. Outsourcing the technical and administrative tasks to an EMB and taking it out of the normal executive hierarchy can contribute to a more professional conduct of elections as well as heightened trust in the electoral process, especially if the EMB is permanent and composed of experts. As has been mentioned before, countries with high administrative effectiveness and neutrality often leave the technical tasks to their ordinary administration. We thus assume that the independence of EMBs is less important in countries which have a high level of good governance.

Hypothesis 1b If the general level of administrative capability and neutrality is low, the outsourcing of those tasks to an independent EMB will make the election fairer.

Hypothesis 1c The better the general level of administrative capability and neutrality (good governance), the fairer the electoral process will be, notwithstanding the institutional set-up of the EMB.

\subsubsection{Institutional independence}

If an EMB is part of the government, the minister has the right to issue instructions and thus has the EMB under control. Instructions may be general or specific and they may be allowed only for parts of the competences of the EMB (e.g., only the technical part) or also on the more politicized part. The government may-by general or specific instructions-take direct, and plainly legal, steps in order to secure the election for itself (in a presidential system) or for its necessary majority 
in parliament (in a parliamentary system). Specific instructions in any case make an EMB dependent on the government as also purely technical matters allow for securing elections. If the set-up is such that the government can influence the electoral process in a legal manner, there is less scope for the opposition (or an EOM) to protest. There is thus also more of a coordination problem for citizens. If no external general or specific instructions may be given legally, the independence is at least de iure secured, though of course the other dimensions of independence come to the fore here in order to determine its de facto independence.

Hypothesis 2a An institutionally independent EMB will lead to a higher probability of fair elections.

Hypothesis 2b If the legal system provides for the possibility that members of the executive can give direct orders to the EMB, the probability of unfair election is higher than otherwise, other variables being equal.

A growing number of countries are incorporating fundamental electoral provisions in their constitutions, often including the type, composition and responsibilities of the EMB. Countries like Bangladesh, Costa Rica, Fiji, Ghana, India, Indonesia and Uruguay set-up their respective EMBs as constitutional bodies. This makes it more difficult to alter their status and other constitutionally defined elements. Therefore, a government would find it more difficult to change provisions in order to influence the election. That, though, holds only if the independence is guaranteed in the constitution as otherwise, it might become even more difficult for the opposition to negotiate an independent EMB for the next elections. The constitutional set-up of an EMB conforms to the game theoretic approach of Weingast, as it gives the incumbent a better guarantee that he may win the election in another round, thus shifting the pay-offs from rigging an election. Clearly, such a constitutional amendment needs cooperation in the generation of rules: a consensus to dissent and respect the game in each election.

Hypothesis 2c If the EMB is set-up as an independent body by the constitution, the higher the probability that the election will be fair.

Furthermore, a permanent EMB, or at least an EMB whose duration extends over several electoral cycles will be able to deliver better results. If an EMB is created ad hoc for each election (temporary EMBs), not only could it be staffed with members close to the incumbent government more easily, but also expertise may be missing and thus undue influence may be more easily taken by the incumbent government. The EMB also would be more at the mercy of the normal administrative network which is more likely to be influenced by the government. Furthermore, IAAs can also develop some kind of internal independence, know-how, and legitimacy in the eyes of the citizenry if they are permanent, as, e.g. courts often do. That would also strengthen their powers vis-à-vis other branches of government. Thus, it is hypothesized that:

Hypothesis 2d A permanent EMB will increase the likelihood of a fair election. 


\subsubsection{Personal independence}

Usually, the EMB is constituted of several persons. It might or might not have a president. If it has a president, his/her position will be a major factor determining the personal independence. If the EMB is not hierarchically structured, the position of all members is relevant. Furthermore, recruitment for an EMB may be multiparty based or expert based. ${ }^{53}$ Some countries require expertise in electoral issues or legal expertise as well as non-partisanship and exclude members which hold executive or other posts. The latter might thus give a higher degree of personal independence. If the opposition wants control over the electoral process and should be included in order to participate, a multi-party based EMB may generate more trust. In that case, not impartiality is the idea but equal representation. This may be especially important in transition-to-democracy countries.

Hypothesis 3a Expert EMBs will increase the probability of fair elections unless the election is taking place in a transition-to-democracy phase.

Three aspects will be distinguished when determining the personal independence of the EMB from the executive and the legislature, namely (i) term length (ii) renewability, (iii) appointing organ, and (iv) removal procedure. Life tenure and appointment by others than politicians will guarantee the greatest personal independence, while appointment by politicians for a renewable term generates the lowest independence, as it can be expected to motivate EMBs to cater to the interests of the organ that has the power to re-elect them. Appointment for a nonrenewable fixed term will generate more personal independence than appointment for a renewable term. Independence of the EMB will also depend on the term length and its congruence with the length of the electoral cycle. If the (head of the) EMB term length is only for one election, renewable before each next one, that would impede personal independence.

Hypothesis 3b Life-long tenure or a non-renewable term with a length over several electoral cycles will increase the independence of the (head of the) EMB, which should increase the probability of a fair election.

Nomination and appointment may be done by different branches. Nomination is often done by a different branch of government having the appointing authority or even the populace. The competence on nomination has a gate-keeping function. It will nevertheless be neglected here as the final say is in the appointment procedure. Three basic modes of appointing of the (head of the) EMB can be distinguished. ${ }^{54}$ Those modes are either "pure" or mixed. They are ordered from the mode which generates the lowest degree of personal independence to the mode, which is hypothesized to generate the highest level of personal independence: (i) appointment by members of executive, ${ }^{55}$ (ii) election by the legislature or its subset; (iii) appointment by members of the judiciary.

\footnotetext{
53 (International Institute for Democracy and Electoral Assistance 2006, p. 88 et seqq.).

54 Those procedures are usually determined by the electoral laws.

55 Formal appointment by, e.g., the head of state will not be counted as this is usually a pure formality.
} 
(i) Appointment by members of the executive, which is constituted by the party in power, is probably the "less" common system of appointment for an independent EMB. It would be expected to lead to a high probability of misusing the EMB in the electoral process. ${ }^{56}$ This is especially the case if the government is unlikely to change frequently (as is the case in, for example, Japan).

(ii) The consequences of having the (head of the) EMB appointed by the legislature depends on the political institutions of a country. In parliamentary systems with plurality voting (such as the British), it would not seem to make much of a difference if it is the executive or the legislature that appoints. Both cases generate low personal independence. In contrast, in systems with proportional representation and/or presidential systems, it might very well make a difference, and appointment by the legislature will significantly lower the probability of the EMB being misused in the electoral process. In addition, appointment by the legislature is usually more transparent than by the executive and can entail public debate, which can be seen as an obstacle for the appointment of persons who are expected to be too loyal to the appointing government. Furthermore, the majority of parliament by which a member of the EMB is chosen may be crucial; a two-thirds majority, e.g., would give effective veto-power to minority parties. ${ }^{57}$

(iii) Appointment by a body of judges is expected to lead to a high degree of independence from the executive. It will lead to comparatively more independence than appointment by the executive or the legislature, if the judiciary is independent. ${ }^{58}$

Hypothesis 3c Appointment by the judiciary, given that it is independent, will generate more independence from the parties in power. Appointment by the executive will lead to least independence.

Removal from office is another important factor in the determination of the personal independence. If the (head of the) EMB may be removed at will by the executive, the incentive to resist political pressure will be reduced. The position of the (head of the) EMB varies; some countries allocate them the same protection against removal as to supreme or constitutional court judges. Some countries have explicit provisions for the removal of office, e.g., the need for a two-thirds majority of parliament (as, e.g., in Albania), but a lot do not. Some countries also grant immunity to the (head of the) EMB shielding them against criminal procedures as they do for high level judges. Here, a de facto indicator may also be generated which illustrates the de facto term length of a member in comparison with the de iure term length.

\footnotetext{
56 (International Institute for Democracy and Electoral Assistance 2006, p. 96).

57 As, e.g., in Mexico, Nigeria, Uruguay and Yemen.

58 In Costa Rica, e.g., the Supreme Court of Justice unilaterally appoints the members of the EMB by a two-thirds majority.
} 
Hypothesis 3d Protection against arbitral removal and immunity form prosecution will enhance the personal independence of the (head of the) EMB and lead to a higher likelihood of fair elections.

\subsubsection{Financial independence}

Starving an EMB of money to fulfill its tasks, no matter how independent it is de iure, will heavily influence its de facto independence. Most countries have chosen to have parliament determining the budget of the EMB instead of the president or the prime minister. ${ }^{59}$ In seven countries, the president determines the budget: Argentina, Chile, Ecuador, Mali, Micronesia, Panama, Paraguay. In four countries, it is the prime minister (Cambodia, Mauritius, Puerto Rico, Tonga). A national government department or some other organ within the national government chooses the budget in 26 countries ${ }^{60}$ In 92 countries, the budget is determined by the legislator. Whether that contributes to the independence of the EMB depends on how many parties are represented in parliament. Nevertheless, it may safely be assumed that parliament will be more representative than the executive and therefore that the budget will not be used for partisan purposes. Budgetary independence is thus one measure which may be an indicator of de facto independence. If the EMB has the possibility of accepting funds also from international organizations, its de facto independence will increase further. Here, the interplay with EOMs may also come to the fore. If external funds include technical assistance, e.g., means of communication for the EMB, the possible control of the electoral process through the activation of public opinion possibly changes the pay-off from rigging an election (vulnerability) but may also increase availability of the voters. It may also mitigate the administrative inefficiency problem by providing funds for technical assistance. Budgetary independence is thus one measure which may be an indicator of de facto independence.

Hypothesis 4a If the budget of the EMB is determined by parliament, the higher the probability that the election will be fair.

Hypothesis $4 b$ The possibility of accepting funds from International Organizations by the EMB increases the probability of a fair election.

\subsubsection{Accountability of EMBs}

When it comes to adjudicatory functions of an EMB, independence and accountability may be at counter trends. An EMB may either have adjudicatory functions itself or those functions may be exercised by a specialized court (as in Mexico) or by the general courts, usually the highest court in the country. Clearly, this allows for crosschecking of decisions of the EMB and thus augments an EMB's accountability. But one needs to look carefully at the competences an EMB has and which ones of those

\footnotetext{
${ }^{59}$ Cf. http://aceproject.org/epic-en/em/Epic_view/EM04 (last modified March 4, 2006).

${ }^{60}$ Belgium, Bosnia and Herzegovina, Bulgaria, Burkina Faso, Central African Republic, Congo (Brazzaville), Czech Republic, Dominica, French Polynesia, Guyana, India, Italy, Japan, Madagascar, Marshall Islands, Mexico, Nepal, New Caledonia, Portugal, Saint Vincent and the Grenadines, Tuvalu, Wallis and Futuna.
} 
are open to adjudicatory control. If the EMB has, e.g., the competence to disqualify candidates, thus infringing on individual rights (passive or active voting rights), an internal review mechanism alone might be insufficient, as individual rights may be at stake, thus requiring review by an independent court. If an EMB has purely administrative tasks, it might be more acceptable to have only an internal review mechanism. Nevertheless, if, e.g., the voters registration list is rigged, opposition parties or other state organs could or could not have the possibility of having standing to review the list. As standing rights have a gate-keeping function for the accountability of EMBs, the broader the standing right, the higher the accountability. If the courts are independent, an external review is desirable as this would augment the accountability. This argument applies to law application as well as law making competences of EMBs. If courts are not independent and judicial review is allowed, than the independence of EMBs might be a de facto farce as the government may take influence through the courts and thus be able to reverse any decision made by an independent EMB. Thus, court control can cut both ways:

Hypothesis 5a The broader the scope of judicial review of the decisions of the EMB, the higher the probability of fair elections iff the courts are de facto independent.

\section{International election monitoring: A third form of accountability}

Outsourcing tasks to the international or supranational level in order to make commitments credible is by no means restricted to elections. ${ }^{61}$ NGOs and International Organizations can even become a functional surrogate for domestic institutions which are not (yet) established or up to their task (e.g., outsourcing issues to international organizations and courts in human rights issues, environmental issues, trade and investment). In contrast, as elections are thought to be a pure internal matter, a matter of domestic sovereignty, the boundary between the national and the international sphere is more tightly drawn in electoral issues than, e.g., in economic matters. Nevertheless, an erudition of domestic sovereignty can be observed as international election observation has become an ever bigger "business" since the end of the cold war as democracy has spread around the world, starting with the invitation of international observers of the Noriega government of Nicaragua in 1989. ${ }^{62}$ International monitoring sits at the intersection of the "right" of the people to democratic governance on the one hand and sovereignty rights of states on the other

\footnotetext{
61 See, e.g., (Voigt et al. 2007) on the Judicial Committee of the Privy Council.

62 (Pastor 1999b, p. 125) classifies Nicaragua as the first observer mission similar to those conducted now. The United Nations first called upon to observe elections in 1,947 on the Korean peninsula. Through the era of trusteeship and decolonization, the United Nations supervised and observed plebiscites, referenda and elections worldwide even before the end of the cold war. UN-monitored elections were key elements of the transitions to peace in places such as Namibia, Cambodia, and Central America and in helping bring about the end to apartheid. Today, the United Nations rarely fields its own observers. This task is more commonly carried out by regional organizations and international NGOs, frequently in conjunction with national groups. The OSCE, the EU, the Carter Center (US) as well as many other actors are involved, usually cumulatively in one place. The OSCE alone has conducted more than 150 EOMs between 1990 and 2005. See (Binder 2008), (Donno 2006) and (Hyde 2004).
} 
hand. Technically speaking though, if we do not talk about cases where the United Nations or some other power administer territories (as e.g., in Kosovo), there is no infringement of sovereignty as states need to invite international observers. Whole substitution of the tasks of an EMB is thus rare and usually only to be found in administered territories. Partial substitution is found often-EOMs thus acquire partially national administrative functions.

International election observation is believed to have the potential to enhance the integrity of election processes, by deterring and exposing irregularities and fraud and by providing recommendations for improving electoral processes. The latter is especially important for transitional countries. It is also thought to promote public confidence, as warranted, promote electoral participation and mitigate the potential for electionrelated conflict. ${ }^{63}$ Thus, by inviting international observers, a government „buys” expertise and credibility. Furthermore, it enhances its vulnerability by submitting to monitoring - as the verdict might create a focal point and enhance coordination of citizens and the opposition to oppose a rigged election (as e.g., in Ethiopia in 2005). The dictum of an international mission that the election has not been free and fair might stir internal unrest. A negative verdict might also provoke reactions by the international community or other states, e.g., by cutting development aid, by denying trade preferences or by generating unfavorable reputational effects for the government as being illegitimate. Furthermore, the international community may sanction the incumbent directly by introducing a visa ban and the freezing of assets. ${ }^{64}$ Nevertheless, those possible sanctions by the international community might not be implemented if the country has any other geo-political importance, as e.g., Egypt or Ethiopia.

The legal basis for an EOM is usually a Memorandum of Understanding (MoUs), thus a non-legally binding instrument. Those MoUs contain the basic rights and duties of the election observers and usually guarantee them free access to all relevant material and places. ${ }^{65}$ In order for an EOM to effectively and credibly conduct its work, basic conditions must be met. An EOM therefore should not be organized unless the country holding the election guarantees certain rights to the observers. The observers guarantee to behave according to the Codes of Conduct for Election Observers. ${ }^{66}$

The influence of international election observers has not been empirically tested for the level of democracy as such, ${ }^{67}$ in spite of the huge efforts and budget put into them. The effect of EOMs on the fairness of elections can cut two ways: Either ex ante by the

\footnotetext{
${ }^{63}$ For a discussion of the potential and limits of EOMs from a legal point of view, see (Binder 2008).

64 This happened, e.g., after the flawed presidential elections in Belarus, where the EU Council adopted those measures, Council Common Position 2006/276/CFSP of 10th April 2006 Concerning Restrictive Measures Against Certain Officials of Belorus (2006) OJ L1001/5.

65 E.g. the MoU between the EU and Ethiopia for the elections of 2005, Art. 4: "The Parties agree that members of the European Union Observer Mission shall enjoy freedom of movement without prior notification throughout the country and shall have free access to all polling stations, counting/tabulation/ aggregation centres, the media, political parties, candidates, voters and civil society representatives. 2. The Parties also agree that European Union election observers shall have access to all election officials and relevant information until the completion of the election process."

66 (United Nations 2005), (European Commission 2008).

${ }^{67}$ But see (Hyde 2004) and (Donno 2006).
} 
technical advice given to the country (thus making the administrative tasks of the election more trustworthy). Here, much depends on the scope of the task ("highscope" missions or small short term observers ${ }^{68}$ ) of EOMs. Or, by sanctioning the incumbent government ex post through indirect means and thus altering the pay-off of the government for rigging elections. Given that there is no direct (international) legal mechanism for sanctioning an unfair election, two hypotheses can be tested for a $\mathrm{d} e$ facto effect:

Hypothesis 5a Countries with a weak technical system of election administration will have fairer elections if there are election observers.

Hypothesis 5b Countries receiving a high level of development aid (in relation to GDP) will have fairer elections if there are election observers.

\section{Conclusion and outlook}

Drawing on different strands of literature, this paper constitutes a first step towards analyzing the incentives-and the ensuing effects-generated by alternative institutional arrangements concerning the set-up of EMBs in interaction with EOMs. If free and fair elections are a necessary condition of democracy and if the fairness and freeness of an election depends also on the institutional organization of the electoral process, the set-up of EMBs can be assumed to have an effect on the level of democracy. Within the framework of constitutional political economy, that is a well accepted assumption but it has never been tested empirically using detailed institutional data. This paper remains for now at a conceptual stage and the empirical work concerning EMBs and EOMs remains to be done. Whereas there is, though not sufficiently detailed work on EMBs by NGOs such as IDEA, there has been no more than anecdotal evidence on the effects of the institutional set-up of EMBs and EOMs on the level of democracy. This is even more astonishing as international observer missions have become very important all over the world and their dicta are widely reported in the press.

There are many more issues and influencing variables to be explored in this context. Also there is no one-size-fits-all EMB. Rather, the institutional set-up has to be adopted to the political and social circumstances of a given country. It seems worth to explore under what circumstances what kind of set-up is enhancing fair and free elections.

A further interesting research question is to endogenize EMBs. This research would ask the following questions: Under what circumstances do countries set-up independent EMBs with a variety of competences? Under what circumstances do they admit EOMs and to what extent? As identified only anecdotally, the less established a democracy and the lower the administrative effectiveness of a country, the higher the probability that it delegates administrative electoral tasks to an independent EMB.

Acknowledgements I wish to thank Rekha Oleschak, Fabienne Ochsner and Malwina Nowakowska for very helpful research assistance and in particular Stefan Voigt for helpful comments. Comments by the

68 (Donno 2006). 
participant at the workshop "The New Separation of Powers" in Haifa, Israel were particulary helpful, especially the comment by Amnon Reichman.

\section{References}

Alesina, A., \& Tabellini, G. (2004). Bureaucrats or Politicans? NBER Working Paper 10241. Available at: http://www.nber.org/papers/w10241. Accessed 8 Dec 2008.

Arnone, M., Bernard, L., Segalotto, J.-F., Sommer, M. (2007). Central Bank Autonomy: Lessons from Global Trends, IMF Working Paper No. 07/88. Available at SSRN: http://ssrn.com/abstract=986816. Accessed 8 Dec 2008.

Bartolini, S. (1999). Collusion, competition and democracy. Part I. Journal of Theoretical Politics, 11, $435-470$.

Bartolini, S. (2000). Collusion, competition and democracy. Part II. Journal of Theoretical Politics, 12, 33-65.

Beck, T., George, R. G. C., Alberto, G., \& Philip, K. (2000). New tools and new tests in comparative political economy: The Database of Political Institutions, World Bank Policy Research Working Paper No. 2283. Available at SSRN: http://ssrn.com/abstract=629133(200). Accessed 8 Dec 2008.

Binder, C. (2008). International Election Observation and Democracy. In E. Harald, K. Lachmayer, G. Ribarov, \& G. Thallinger (Eds.), Perspectives and Limits of Democracy (pp. 71-90). Wien: Nomos/wuv.

Buchanan, J. M. (1975). The Limits of Liberty-Between Anarchy and Leviathan. Chicago: Chicago University Press.

Dahl, R. A. (1971). Polyarchy, Participation and Opposition. New Haven: Yale University Press.

Diamond, L., Plattner, M. F., Andreas, S. (1999). Introduction. In A. Schedler, L. Diamond, \& M. F. Plattner (Eds.), The Self-Restraining State: Power and Accountability in New Democracies (pp 1-10). Boulder, CO: Lynne Rienner Publishers.

Donno, D. (2006). The International and Domestic Politics of Election Manipulation. Paper presented at the annual meeting of the American Political Science Association. Retrieved Aug 31, 2006, from http://www.allacademic.com/meta/p151446_index.html.

Downs, A. (1968). Ökonomische Theorie der Demokratie. Tübingen: Siebeck/Mohr.

Dutzler, B. (2002). Der Status des ESZB aus demokratietheoretischer Sicht. Der Staat, 41, 495-522.

Eisenstadt, T. A. (2002). Measuring electoral court failure in democratizing Mexico. International Political Science Review, 23, 47-68.

Elklit, J., \& Reynolds, A. (2002). The impact of election administration on the legitimacy of emerging democracies: A new comparative politics research agenda. Journal of Commonwealth and Comparative Politics, 40, 86-119.

Elklit, J., \& Reynolds, A. (2005). A framework for the systematic study of election quality. Democratization, 12, 147-162.

European Commission. (2008). Handbook for European Union Election Observation.

Feld, L. P., \& Voigt, S. (2003). Economic growth and judicial independence: Cross-country evidence using a new set of indicators. European Journal of Political Economy, 19, 497-527.

Franck, T. M. (1992). The emerging right to democratic governance. American Journal of International Law, 86, 46-91.

Freedom House. (2008). Freedom in the World 2008. Selected Data from the Houses' Annual Global Survey of Political Rights and Civil Liberties, www.freedomhouse.org.

Gilardi, F., Jordana, J., \& Levi-Faur, D. (2006). Regulation in the age of globalization: The diffusion of regulatory agencies across europe and latin america. In H. Graeme (Eds.), Privatisation and Market Development: Global Movements in Public Policy Ideas (pp. 127-147). Cheltenham: Edward Elgar.

Hyde, S. D. (2004). Foreign democracy promotion, norm development and democratization: Explaining the causes and consequences of internationally monitored elections. Dissertation Prospectus.

International Institute for Democracy and Electoral Assistance. (2006). Electoral management design: The International IDEA Handbook: Publications Office International IDEA.

Lijphart, A. (1999). Patterns of democracies: Government forms and performance in thirty-six countries, New Haven: Yale University Press.

Lipset, S. M. (1959). Some social requisites of democracy: Economic development and political legitimacy. American Political Science Review, 53, 69-105. 
Madison, J. (1788). Federalist Papers, No. 51, London.

Majone, G. (2001). Nonmajoritarian institutions and the limits of democratic governance: A political transaction-cost approach. Journal of Institutional and Theoretical Economics, 157, 57-78.

Mozaffar, S., \& Schedler, A. (2002). The comparative study of electoral governance-introduction. International Political Science Review, 23, 5-27.

Munck, G. L., \& Verkuilen, J. (2002). Conceptualizing and measuring democracy: Evaluating alternative indices. Comparative Political Studies, 35, 5-34.

Pastor, R. A. (1998). Mediating elections. Journal of Democracy, 9(1), 154-163.

Pastor, R. A. (1999a). The role of electoral administration in democratic transitions: Implications for policy and research. Democratization, 6(4), 1-27.

Pastor, R. A. (1999b). The third dimension of accountability: The international community in national elections. In A. Schedler, L. Diamond, \& M. F. Plattner (Eds.), The Self-Restraining State: Power and Accountability in New Democracies (pp. 123-142). Boulder, CO: Lynne Rienner Publishers.

Przeworski, A. (1988). Democracy as a contingent outcome of conflicts. In R. Slagsted \& J. Elster (Eds.). Constitutionalism and Democracy (pp. 59-80). New York: Cambridge University Press.

Przeworski, A. (1991). Democracy and the market. New York: Cambridge University Press.

Quintyn, M. (forthcoming). Independent agencies: More than a cheap copy of independent central banks? In this volume. doi:10.1007/s10602-008-9064-2.

Salzberger, E. (1993). A positive analysis of the doctrine of separation of powers, or: Why do we have an independent judiciary? International Review of Law and Economics, 13, 349-379.

Schelling, T. C. (1960). The strategy of conflict. Cambridge (Mass): Harvard University Press.

Schumpeter, J. A. (1950). Kapitalismus, Sozialismus und Demokratie. Tübingen: Siebeck/Mohr.

Sunde, U. (2006). Wirtschaftliche Entwicklung und Demokratie-Ist Demokratie ein Wohlstandsmotor oder ein Wohlstandsprodukt? Perspektiven der Wirtschaftspolitik, 7, 471-499.

United Nations. (2005). Declaration of Principles for International Election Observation and Code of Conduct for International Election Observers. Available at: http://www.accessdemocracy.org/ library/1923_declaration_102705.pdf. Accessed 8 Dec 2008.

Van Aaken, A. (2005). Independent Administrative Authorities in Germany. In R. Caranta, A. Mads, \& F. Duncan (Eds.), Independent Administrative Authorities: The European way(s) (pp. 65-91). London: British Institute of International and Comparative Law.

Voigt, S., Ebeling, M., \& Blume, L. (2007). Improving credibility by delegating judicial competencethe case of the Judicial Committee of the Privy Council. Journal of Development Economics, 82, 348-373.

Voigt, S., \& Salzberger, E. (2002). Choosing not to choose: When politicians choose to delegate powers. Kyklos, 55, 247-268.

Weingast, B. (1997). The political foundations of democracy and the rule of law. American Political Science Review, 91, 245-263. 